\title{
PENGARUH PERSEPSI WAJIB PAJAK ORANG PRIBADI TERHADAP TINDAKAN PENGGELAPAN PAJAK DI KOTA SURAKARTA
}

\author{
Devi Marta Ardi ${ }^{1}$, Trimurti $^{2}$, Suhendro ${ }^{3}$ \\ Jurusan Akuntansi, Fakultas Ekonomi, Universitas Islam Batik Surakarta \\ Jl. KH. Agus Salim No. 10 Surakarta 57147, Telp. 0271-714751 \\ Email: devimartaardi@gmail.com
}

\author{
submited: 2016.01.30 reviewed: 2016.04.18 accepted: 2016.06 .30 \\ http://dx.doi.org/10.22202/economica.2016.v4.i2.384
}

\begin{abstract}
This study aims to determine the effect of an individual taxpayer's perception regarding the understanding of taxation, the taxation system, justice, discrimination against acts of tax evasion. Population and sample in this study individual taxpayers, especially businesses with a turnover not exceeding 4.8 billion in a tax year. Sampling techniques performed by using Convenience Sampling, data were collected with the distribution of questionnaires to 100 respondents. Methods of data analysis using multiple linear regression analysis. Based on the results of the analysis indicate that in partial understanding of taxation affect the actions of tax evasion, the tax system affect the actions of tax evasion, justice does not affect the actions of tax evasion and discrimination affect the tax evasion measures. While, simultaneously variable understanding of taxation, the taxation system, justice, discrimination affect the tax evasion measures.
\end{abstract}

\begin{abstract}
Abstrak
Penelitian ini bertujan untuk mengetahui pengaruh persepsi wajib pajak orang pribadi mengenai pemahaman perpajakan, sistem perpajakan, keadilan, diskriminasi terhadap tindakan penggelapan pajak. Populasi dan sampel dalam penelitian ini wajib pajak orang pribadi khususnya pengusaha dengan omset tidak melebihi 4,8 miliar dalam satu tahun pajak. Tehnik pengambilan sampel dilakukan dengan menggunakan Convenience Sampling, data dikumpulkan dengan pembagian kuesioner kepada 100 responden. Metode analisis data menggunakan analisis regresi linier berganda. Berdasarkan hasil analisis menunjukkan bahwa secara parsial variabel pemahaman perpajakan berpengaruh terhadap tindakan penggelapan pajak, sistem perpajakan berpengaruh terhadap tindakan penggelapan pajak, keadilan tidak berpengaruh terhadap tindakan penggelapan pajak dan diskriminasi berpengaruh terhadap tindakan penggelapan pajak. Sedangkan, secara simultan variabel pemahaman perpajakan, sistem perpajakan, keadilan, diskriminasi berpengaruh terhadap tindakan penggelapan pajak.
\end{abstract}

Keywords: Persepsi, Penggelapan Pajak 


\section{PENDAHULUAN}

Indonesia sebagai negara yang sedang berkembang perlu meningkatkan pertumbuhan dan perekonomian negara agar dapat bersaing dengan bangsa lain. Untuk mewujudkannya Negara Indonesia memerlukan sumber dana yang cukup besar. Salah satu sumber dana terbesar untuk membiayai keperluan negara berasal dari pajak. Menurut Undang-undang Perpajakan No. 6 Tahun 1983 Tentang Ketentuan Umum dan Tata Cara Perpajakan, Pajak adalah kontribusi wajib kepada negara yang terutang oleh orang pribadi atau badan yang bersifat memaksa berdasarkan Undang-undang, dengan tidak mendapatkan imbalan secara langsung dan digunakan untuk keperluan negara bagi sebesar-besarnya kemakmuran rakyat.

Walaupun penerimaan pajak mengalami peningkatan di sektor tertentu dari tahun sebelumnya, tetapi peningkatan ini belum mencapai pada target yang diharapkan. Kondisi seperti ini menimbulkan berbagai anggapan masyarakat yang berprasangka bahwa terjadi tindakan penggelapan pajak. Selain itu, adanya kasus-kasus penggelapan pajak yang terjadi, salah satunya kasus tertangkapnya petugas pajak Gayus Tambunan yang berusaha menyelewengkan pajak dengan bekerjasama dengan wajib pajak, juga mendukung masyarakat untuk melakukan penggelapan pajak. Jika hal ini dibiarkan berlarut-larut, maka lama kelamaan akan membuat masyarakat sebagai wajib pajak, untuk ingkar dari kewajiban perpajakannya.

Dana pajak bersumber dari wajib pajak yang menyetorkan kewajiban pajaknya, baik wajib pajak orang pribadi pengusaha maupun non-pengusaha dan wajib pajak badan. Wajib pajak yang menyetorkan kewajiban perpajakannya salah satunya, yaitu wajib pajak orang pribadi pengusaha. Apabila dibandingkan dengan wajib pajak badan, laba yang dihasilkan wajib pajak orang pribadi pengusaha lebih kecil. Hal ini berdampak pada jumlah pajak yang dibayarkan oleh wajib pajak orang pribadi pengusaha ke kas negara juga lebih kecil daripada wajib pajak badan, situasi ini dikarenakan anggapan bagi wajib pajak orang pribadi pengusaha bahwa daripada untuk membayar pajak, lebih baik untuk mengembangkan usaha. Sehingga, mengindikasikan untuk melakukan penggelapan pajak.

Kurangnya pemahaman mengenai pentingnya pajak dan tujuan pajak juga memicu masyarakat untuk melakukan penggelapan pajak. Keadaan ini didukung dengan keengganan masyarakat untuk membayar pajak yang disebabkan minimnya pengetahuan masyarakat dalam perpajakan. Karena sebagian masyarakat menganggap bahwa pajak merupakan hal yang tidak terlalu penting dan hanya menjadi beban kebutuhannya.

Dalam pencapaian untuk memaksimalkan penerimaan pajak, diperlukan sistem perpajakan yang mendukung. Pada umumnya, sistem perpajakan ada tiga yaitu official assessment system, self assessment system, dan withholding system. Sejalan dengan perkembangan jaman, saat ini Indonesia menerapkan sistem self assessment yaitu dimana wajib pajak berperan aktif dan memiliki wewenang untuk melaporkan sendiri pajak terutangnya, mulai dari mendaftarkan diri sebagai wajib pajak, menghitung pajak terutangnya hingga menyetorkannya ke kas negara, dan fiskus hanya sebagai pengawas. Pada sistem ini akan berjalan dengan baik, jika kesadaran wajib pajak tinggi sebab wajib pajak dapat menghitung sendiri pajaknya sehingga ada kesempatan untuk meminimalkan pajak terutangnya.

Sebagai sumber dana terbesar, diharapkan ouput dari penggunaan dana pajak dapat secara adil dirasakan oleh semua masyarakat. Namun, faktanya hanya sebagian masyarakat yang merasakan pembangunan atau fasilitas yang berasal dari pajak. Hal ini menjadi bukti bahwa penggunaan dana pajak belum optimal sehingga menjadikan opini masyarakat jika terjadi penyelewengan dalam penggunaan 
dana pajak. Selain itu, pemerintah dikatakan adil apabila kebijakan-kebijakan yang dibuat tidak hanya menguntungkan pihak-pihak tertentu saja. Namun, diharapkan semua pihak dapat merasakan kebijakan-kebijakan yang ditentukan tanpa adanya perbedaan perlakuan. Seperti, kebijakan zakat yang diperbolehkan sebagai pengurang kewajiban pajak bagi umat muslim yang membayar kewajiban zakatnya pada lembaga zakat. Hal ini dirasakan sebagai perbedaan perlakuan antara umat muslim dan non-muslim. Maka, ketidakseimbangan perlakuan ini membuat masyarakat untuk cenderung tidak taat pada aturan dan beropini bahwa penggelapan pajak pantas dilakukan.

Berdasarkan latarbelakang yang telah dipaparkan diatas, maka masalah yang akan dicapai dalam penelitian ini adalah: Apakah persepsi wajib pajak orang pribadi mengenai pemahaman perpajakan, sistem perpajakan, keadilan, diskriminasi berpengaruh terhadap tindakan penggelapan pajak?. Dari rumusan masalah yang ada, maka tujuan penelitian yang akan dicapai adalah untuk mengetahui pengaruh persepsi wajib pajak orang pribadi mengenai pemahaman perpajakan, sistem perpajakan, keadilan, diskriminasi terhadap tindakan penggelapan pajak.

\section{Pajak}

Pajak adalah iuran yang dapat dipaksakan, dimana pemerintah dapat memaksa Wajib Pajak untuk memenuhi kewajibannya dengan menggunakan surat paksa dan sita. Setiap Wajib Pajak yang membayar iuran atau pajak kepada negara tidak akan mendapat balas jasa yang langsung dapat ditunjukkan. Tetapi imbalan yang secara tidak langsung diperoleh Wajib Pajak berupa pelayanan pemerintah yang ditujukan kepada seluruh masyarakat melalui penyelenggaraan sarana irigasi, jalan, sekolah, dan sebagainya (Rahman, 2013). Sedangkan menurut Undang-undang Perpajakan No. 6 Tahun 1983 Tentang Ketentuan Umum dan Tata Cara Perpajakan, Pajak adalah kontribusi wajib kepada negara yang terutang oleh orang pribadi atau badan yang bersifat memaksa berdasarkan Undang-undang, dengan tidak mendapatkan imbalan secara langsung dan digunakan untuk keperluan negara bagi sebesar-besarnya kemakmuran rakyat.

Menurut Mardiasmo (2009) salah satu jenis pajak menurut golongannya, terdiri:

1. Pajak langsung, adalah pajak yang harus dipikul atau ditanggung sendiri oleh Wajib Pajak dan tidak dapat dilimpahkan atau dibebankan kepada orang lain atau pihak lain.

2. Pajak tidak langsung, adalah pajak yang akhirnya dapat dibebankan atau dilimpahkan kepada orang lain atau pihak ketiga.

\section{Persepsi}

Menurut Abizar (1998) dalam Prasetyo (2010) persepsi adalah suatu proses dengan mana seorang individu memilih mengevaluasi dan mengorganisasi stimulus dari lingkungannya. Persepsi juga menentukan cara kita berperilaku atas suatu objek atau permasalahan, bagaimsana segala sesuatu itu mempengaruhi persepsi seseorang nantinya akan mempengaruhi perilaku yang dipilihnya. Persepsi terbentuk dari pengamatan melalui proses melihat, mendengar, menyentuh, merasakan, menerima suatu hal yang selanjutnya seseorang menseleksi, mengorganisasi dan mengintepretasikan informasi yang diterima menjadi suatu gambaran. Pengaruh persepsi dalam membentuk perilaku individu sebagai warga negara dalam rangka memenuhi kewajiban membayar pajak sesuai dengan aturan perundang-undangan yang berlaku, sebagai konklusi tentang persepsi individu bahwa persepsi adalah proses menerima, mengorganisasikan dan mengartikan suatu obyek (Gibson, 2001).

Dengan demikian persepsi adalah suatu asumsi atau suatu informasi dari seseorang yang didapat dari pengalaman masa lalu yang dirasakan sendiri oleh 
indera orang tersebut, keinginan seseorang dalam membuat keputusan dan dari informasi yang diberikan oleh orang lain. Dalam hal ini bisa dikatakan bahwa persepsi penggelapan pajak timbul akibat pengalaman Wajib Pajak itu sendiri, dari keinginan Wajib Pajak untuk melakukan penggelapan pajak terhadap perpajakan Indonesia yang membuat persepsi tentang penggelapan pajak dianggap sebagai hal yang wajar (Wicaksono, 2014).

\section{Pemahaman Perpajakan}

Keberhasilan dalam perpajakan dipengaruhi oleh perilaku wajib pajak yang berkaitan dengan pemahaman terhadap undang-undang dan peraturan perpajakan. Oleh karena itu, pemahaman wajib pajak tentang perpajakan berupa informasi perpajakan dan peraturan perpajakan akan meningkatkan kesadaran wajib pajak dalam membayar kewajiban perpajakannya. Pemahaman Wajib Pajak terhadap undang-undang dan peraturan perpajakan serta sikap Wajib Pajak mempengaruhi perilaku perpajakan Wajib Pajak dan akhirnya perilaku perpajakan mempengaruhi keberhasilan perpajakan (Sholichah, 2005). Selain itu, pentingnya pemahaman pajak mengenai fungsi dari pajak untuk membiayai keperluan negara guna kemakmuran rakyatnya yang kuat, mandiri dan sejahtera, diharapkan agar masyarakat taat membayar pajak sehingga tindakan penggelapan pajak dapat diminimalisasikan.

Persoalan mengenai tingkat pemahaman perpajakan dari wajib pajak dirasa perlu untuk dibahas karena pengetahuan perpajakan adalah salah satu faktor potensial bagi pemerintah untuk meningkatkan ketaatan wajib pajak dalam memenuhi kewajiban perpajakannya, semakin tinggi tingkat pengetahuan dan pemahaman wajib pajak terhadap peraturan perpajakan, maka semakin kecil pula kemungkinan wajib pajak tersebut untuk melanggar peraturan tersebut, karena jika pengetahuan mengenai perpajakan rendah, maka ketaatan wajib pajak mengenai peraturan yang berlaku juga rendah (Spicer and Lundsent, 1976 dalam Mutia, 2014).

Adanya pemahaman tentang tindakan penggelapan pajak, memiliki tujuan supaya praktik penggelapan pajak dapat diminimalkan dari kesalahan melaporkan dan membayar utang perpajakannya. McGee (2009) dalam Rachmadi (2014), dalam penelitiannya mengaitkan sistem perpajakan dan pemahaman Undang-Undang perpajakan dapat berjalan dengan semestinya serta kemungkinan penyalahgunaan dalam sistem apapun. Wajib Pajak akan menganggap buruk dan cenderung menghindari suatu tindakan yang melanggar ketentuan apabila pemahaman yang dimilikinya semakin baik. Dari hal tersebut, maka dapat dirumuskan hipotesis: $\mathrm{H}_{1}$ : Persepsi Wajib Pajak Orang Pribadi mengenai pemahaman perpajakan berpengaruh terhadap tindakan penggelapan pajak.

\section{Sistem Perpajakan}

Unsur penting yang mendukung keberhasilan pemungutan pajak suatu negara yaitu salah satunya dengan adanya sistem perpajakan. Sistem perpajakan secara umum ada tiga, yaitu official assessment system, self assessment system, dan withholding system. Menurut Mardiasmo (2011), sistem perpajakan official assessment system merupakan sistem pemungutan pajak dengan memberi wewenang kepada pemerintah (fiskus) untuk menentukan besarnya pajak yang terutang oleh wajib pajak. Sedangkan sistem self assessment system merupakan sistem pemungutan pajak dengan memberi wewenang kepada Wajib Pajak untuk menentukan sendiri besarnya pajak yang terutang. Sistem withholding system merupakan sistem pemungutan pajak dengan memberi wewenang kepada pihak ketiga (bukan Fiskus atau bukan Wajib Pajak yang bersangkutan) untuk menentukan besarnya pajak yang terutang oleh Wajib Pajak. Di Indonesia sistem perpajakan yang diterapkan yaitu self assessment system, yang dimulai sejak 
reformasi tahun 1983. Dengan berbagai akses kemudahan wajib pajak dalam membayarkan pajaknya, diharapkan wajib pajak dapat melaksanakan pemenuhan kewajibannya dengan baik. Sistem pembayaran pajak yang berlaku di Indonesia memberikan kebebasan dan tanggung jawab penuh dari dalam diri wajib pajak, sehingga diharapkan secara bersama-sama seluruh wajib pajak bisa mewujudkan ketaatannya dalam kehidupan bernegara khususnya untuk membayarkan kewajiban pajaknya yang digunakan untuk pembangunan nasional (Rahman, 2013).

Dalam penelitian Suminarsasi \& Supriyadi (2012) menunjukkan bahwa para wajib pajak menganggap bahwa semakin bagus sistem perpajakannya maka perilaku penggelapan pajak dianggap sebagai perilaku yang tidak etis. Akan tetapi apabila sistem perpajakannya semakin tidak bagus, maka perilaku penggelapan pajak dianggap sebagai perilaku yang cenderung etis. Penerapan sistem ini sebagai pedoman wajib pajak, jika sistem ini berjalan dengan baik maka tanggapan wajib pajak untuk taat peraturan juga baik. Sebaliknya, jika sistem ini berjalan kurang baik maka tanggapan wajib pajak untuk taat peraturan juga kurang baik. Dari hal tersebut, maka dapat dirumuskan hipotesis: $\mathrm{H}_{2}$ : Persepsi Wajib Pajak Orang Pribadi mengenai sistem perpajakan berpengaruh terhadap tindakan penggelapan pajak.

\section{Keadilan}

Mardiasmo (2009) mengutarakan bahwa sesuai dengan tujuan hukum, yakni mencapai keadilan, undang-undang dan pelaksanaan pemungutan harus adil. Adil dalam perundang-undangan diantaranya mengenakan pajak secara umum dan merata, serta disesuaikan dengan kemampuan masing-masing. Sedangkan adil dalam pelaksanaannya yakni dengan memberikan hak kepada wajib pajak untuk mengajukan keberatan, penundaan dalam pembayaran dan mengajukan banding kepada Majelis Pertimbangan Pajak. Sudut pandang keadilan yang luas, menimbulkan permasalahan dalam pemungutan pajak mengenai cara mewujudkan keadilan pajak, sebab keadilan menurut masingmasing individu juga berbeda. Oleh sebab itu, penerapan pajak sebagai sumber penerimaan negara yaitu masyarakat secara merata dapat merasakan keadilan dalam pelaksanaan undang-undang pajak dan manfaat dari penggunaan dana pajak.

Menurut Siahaan (2010), keadilan dibagi menjadi tiga aliran pemikiran, yaitu:

a. Prinsip Manfaat (Benefit Principle)

Prinsip ini menyatakan bahwa suatu sistem pajak dikatakan adil apabila kontribusi yang diberikan oleh setiap wajib pajak sesuai dengan manfaat yang diperolehnya dari jasa-jasa pemerintah.

b. Prinsip Kemampuan Untuk Membayar (Ability To Pay)

Menurut prinsip ini, perekonomian memerlukan suatu jumlah penerimaan pajak tertentu, dan setiap wajib pajak diminta untuk membayar sesuai dengan kemampuannya.

c. Keadilan Horizontal Dan Keadilan Vertikal

Suatu pemungutan pajak memenuhi keadilan horizontal apabila wajib pajak yang berada dalam kondisi yang sama diperlakukan sama maksud dan tujuan terhadap tingkat kesetaraan dalam perolehan penghasilan. Wajib pajak yang memiliki tingkat penghasilan yang setara, akan dikenakan pajak yang setara pula. Sedangkan pemungutan pajak diakatakan adil secara vertikal apabila orang-orang dengan tambahan kemampuan ekonomis yang berbeda dikenakan pajak penghasilan yang berbeda setara dengan perbedaannya.

Semakin tinggi keadilan yang dilakukan pemerintah, maka masyarakat akan semakin percaya terhadap kinerja pemerintah, hal ini mendorong kemauan masyarakat untuk membayar pajak dan mempercayai pemerintah dalam mengelola dana yang bersumber dari pajak (Rahman, 2013). Pada penelitian yang dilakukan oleh Ayu \& Hastuti (2009) menunjukkan bahwa keadilan berpengaruh negatif terhadap 
penggelapan pajak. Semakin tinggi tingkat keadilan suatu negara, maka masyarakatnya memiliki persepsi bahwa tindakan penggelapan pajak merupakan tindakan yang tidak etis (Ningsih \& Pusposary, 2014).

$\mathrm{H}_{3}$ : Persepsi Wajib Pajak Orang Pribadi mengenai keadilan berpengaruh terhadap tindakan penggelapan pajak.

\section{Diskriminasi}

Menurut Danandjaja (2003), diskriminasi adalah perlakuan yang tidak seimbang terhadap perorangan, atau kelompok, berdasarkan sesuatu, biasanya bersifat kategorikal, atau atribut-atribut khas, seperti berdasarkan ras, kesukubangsaan, agama, atau keanggotaan kelas-kelas sosial. Perbedaan perlakuan ini bisa terjadi pada wajib pajak yang memiliki kekerabatan dan yang tidak memiliki kekerabatan dengan pihak fiskus. Selain itu perbedaan perlakuan juga terjadi dengan adanya kerjasama antara pihak fiskus dengan wajib pajak yang berusaha untuk meminimalisasikan jumlah pajak terutangnya.

Zakat yang dibayarkan kepada BAZNAS atau LAZIS dapat dikurangkan dari jumlah pajak yang terutang, khususnya pada pajak penghasilan. Hal ini dimaksudkan agar tidak terjadi beban ganda yang dikenakan pada wajib pajak. Kondisi ini juga dijelaskan dalam ketentuan perpajakan Undang-Undang No. 7 Tahun 1983 tentang Pajak Penghasilan, yakni diatur dalam Pasal 4 ayat (3) huruf a nomor 1 yang berbunyi: "Yang dikecualikan sebagai Objek Pajak adalah: bantuan sumbangan, termasuk zakat yang diterima oleh badan amil zakat atau lembaga amil zakat yang dibentuk atau disahkan oleh Pemerintah dan para penerima zakat yang berhak atau sumbangan keagamaan yang sifatnya wajib bagi pemeluk agama yang diakui di Indonesia, yang diterima oleh lembaga keagamaan yang dibentuk atau disahkan oleh pemerintah dan yang diterima oleh penerima sumbangan yang berhak, yang ketentuannya diatur dengan atau berdasarkan Peraturan Pemerintah ". Kebijakan pajak dalam pasal tersebut menguntungkan sebagian kelompok masyarakat saja, sehingga akan mengakibatkan kecemburuan pada kelompok yang tidak menerima keuntungan dari kebijakan tersebut. Sedangkan, pengurangan pajak atas kewajiban pembayaran sumbangan untuk agama lain belum diatur.

Masih adanya masyarakat yang kontra dengan kebijakan peraturan yang berlaku, salah satunya disebabkan oleh pemerintah yang masih melakukan diskriminasi. Penerapan kebijakan pemerintah ini belum merata, karena ada sebagian pihak yang untung dan sebagian yang dirugikan. Penelitian yang dilakukan Suminarsasi \& Supriyadi (2012), membuktikan jika diskriminasi berpengaruh positif terhadap persepsi mengenai etika penggelapan pajak. Maka, semakin rendah tingkat diskriminasi maka perilaku penggelapan pajak dipandang sebagai perilaku yang tidak etis. Dari hal tersebut, maka dapat dirumuskan hipotesis: $\mathrm{H}_{4}$ : Persepsi Wajib Pajak Orang Pribadi mengenai diskriminasi berpengaruh terhadap tindakan penggelapan pajak.

Nickerson, Pleshko, \& McGee (2009), membahas tentang dimensionalitas skala etika tentang penggelapan pajak.Penelitian ini juga menyimpulkan bahwa penggelapan pajak dianggap sebagai yang paling dibenarkan dalam kasus dimana sistem pajak dilihat tidak adil, dana pajak yang terkumpul terbuang sia-sia dan di mana pemerintah mendiskriminasikan beberapa segmen penduduk. Pelaksanaan sistem perpajakan ini akan berhasil, jika wajib pajak paham akan pentingnya pajak itu. Selain itu, kerjasama yang baik antara wajib pajak dan pihak fiskus dan tidak adanya perbedaan perlakuan yang terjadi. Sehinnga, output dari pembayaran pajak digunakan untuk pembangunan negara dapat dirasakan bersama oleh wajib pajak sebagai warga negara. Dari hal tersebut, maka dapat dirumuskan hipotesis: 
$\mathrm{H}_{5}$ : Persepsi Wajib Pajak Orang Pribadi mengenai pemahaman perpajakan, sistem perpajakan, keadilan, diskriminasi berpengaruh secara bersama-sama terhadap tindakan penggelapan pajak

\section{Penggelapan Pajak}

Penggelapan pajak bisa dilakukan dengan memanipulasi data keuangan pada laporan keuangan, dengan menambah jumlah biaya sehingga laba yang dihasilkan menjadi kecil dan berdampak pada jumlah pajak yang dibayarkan semakin kecil pula. Menurut Siahaan (2010) mengatakan bahwa penggelapan pajak adalah usaha yang digunakan oleh wajib pajak untuk mengelak dari kewajiban pajak yang sesungguhnya dan merupakan perbuatan yang melanggar undang-undang pajak, sehingga membawa berbagai macam akibat, meliputi berbagai bidang kehidupan masyarakat, antara lain bidang keuangan, ekonomi, dan psikologi.

Menurut Wallschutzki ada

beberapa alasan yang menjadi pertimbangan Wajib Pajak melakukan penghindaran pajak (Nurmantu, 2003), adalah sebagai berikut:

a. Ada peluang untuk melakukan penghindaran pajak karena ketentuan perpajakan yang ada belum mengatur secara jelas mengenai ketentuanketentuan tertentu

b. Kemungkinan perbuatannya diketahui relatif kecil

c. Manfaat yang diperoleh relatif besar daripada resikonya

d. Sanksi perpajakan yang tidak terlalu berat

e. Ketentuan perpajakan tidak berlaku sama terhadap seluruh Wajib Pajak

f. Pelaksanaan penegakan hukum yang bervariasi

\section{METODE PENELITIAN}

Penelitian ini menggunakan variabel independen pemahaman perpajakan, sistem perpajakan, keadilan, diskriminasi dan variabel dependen tindakan penggelapan pajak. Sampel dalam penelitian ini adalah wajib pajak orang pribadi khususnya pengusaha yang memiliki omset tidak melebihi 4,8 miliar per satu tahun pajak di kota Surakarta. Metode penelitian ini dengan survey yaitu dengan menyebarkan kuesioner kepada responden dan diukur dengan menggunakan skala Likert. Tehnik pengambilan sampel dilakukan dengan tehnik Convenience Sampling yaitu anggota sampel yang dipilih atau diambil berdasarkan kemudahan memperoleh data yang dibutuhkan, atau unit sampel yang ditarik mudah untuk diukurnya dan bersifat kooperatif (Hamid, 2010).

\section{Definisi Oprasional Variabel}

$\begin{array}{llr}\text { Pada } & \text { variabel pemahaman } \\ \text { perpajakan } & \text { diukur dengan } & \text { empat } \\ \text { pertanyaan } & \text { menggunakan indikator } \\ \text { pengukuran: } & \text { pengetahuan kewajiban }\end{array}$ sebagai wajib pajak, pengetahuan hak sebagai wajib pajak, pengetahuan mengenai sanksi perpajakan, pemahaman mengenai peraturan perpajakan. Pada variabel sistem perpajakan diukur dengan empat pertanyaan menggunakan indikator pengukuran: tarif pajak yang diberlakukan di Indonesia, cara penghitungan pajak yang dibayar, kemudahan dalam proses pembayaran pajak, peran aparat perpajakan dalam pelaporan pajak. Pada variabel keadilan diukur dengan empat pertanyaan menggunakan indikator pengukuran: manfaat dari penggunaan dana yang bersumber dari pajak, prinsip kemampuan dalam membayar kewajiban pajak, prinsip keadilan horizontal dalam pajak, keadilan dalam penyusunan undang-undang pajak. Pada variabel diskriminasi diukur dengan empat pertanyaan menggunakan indikator: pengukuran perlakuan yang berbeda atas dasar agama, ras, kebudayaan dan keanggotaan kelas-kelas sosial, pendiskriminasian terhadap hal-hal yang disebabkan oleh manfaat perpajakan, kebijakan yang ditetapkan menguntungkan pihak tertentu saja. 


\section{PEMBAHASAN}

\section{Deskripsi Sampel Penelitian}

Penelitian ini menggunakan metode pengumpulan data dengan kuesioner, penyebaran instrumen angket dengan objek penelitian atau responden yang menjadi sampel yaitu Wajib Pajak Orang Pribadi khususnya pengusaha yang memiliki omset tidak melebihi 4,8 miliar dalam satu tahun pajak. Jumlah kuesioner yang disebar sebanyak 110 kuesioner. Jumlah kuesioner yang kembali sebanyak 104 kuesioner, dan kuesioner yang tidak lengkap sebanyak 4 kuesioner. Sehingga, jumlah kuesioner yang menjadi sampel akhir sebanyak 100 kuesioner.

\section{Uji Statistik Deskriptif}

Berdasarkan tabel 2 (Terlampir), dapat dijelaskan bahwa jumlah responden (N) sebanyak 100 responden. Pada variabel independen pemahaman perpajakan memiliki nilai minimum 12, nilai maksimum 15, nilai mean 13,26 dengan standar deviasi 1,070. Variabel sistem perpajakan memiliki nilai minimum 10 , nilai maksimum 16 , nilai mean 13,45 dengan standar deviasi 1,403. Variabel keadilan memiliki nilai minimum 9, nilai maksimum 14 , nilai mean 11,73 dengan standar deviasi 1,270. Variabel diskriminasi memiliki nilai minimum 8 , nilai maksimum 14 , nilai mean 11,26 dengan standar deviasi 1,447. Sedangkan, pada variabel dependen penggelapan pajak memiliki nilai minimum 11 , nilai maksimum 19, nilai mean 15,04 dengan standar deviasi 1.809.

\section{Uji Validitas}

Berdasarkan tabel hasil penghitungan tabel 3 (Terlampir), diperoleh hasil bahwa nilai $\mathrm{r}$ hitung $>\mathrm{r}$ tabel (0,361), hal ini berarti semua pertanyaan pada variabel independen yang terdiri dari pemahaman perpajakan, sistem perpajakan, keadilan, diskriminasi dinyatakan valid dan dapat digunakan untuk penelitian.

\section{Uji Reliabilitas}

\section{Pada tabel 4 (Terlampir),} menunjukkan bahwa semua pertanyaan dalam kuesioner reliabel dengan nilai Cronbach's Alpha > 0,6. Dijelaskan dalam hasil pengujian pada variabel pemahaman perpajakan dengan nilai Cronbach's Alpha sebesar 0,747, variabel sistem perpajakan dengan nilai Cronbach's Alpha sebesar 0,815 , variabel keadilan dengan nilai Cronbach's Alpha sebesar 0,815, variabel diskriminasi dengan nilai Cronbach's Alpha sebesar 0,794 dan variabel penggelapan pajak dengan nilai Cronbach's Alpha sebesar 0,729. Hal ini berarti kuesioner dijawab oleh responden dengan konsisten.

\section{Pengujian Asumsi Klasik Uji Normalitas}

Berdasarkan tabel 5 (Terlampir), diperoleh hasil nilai signifikansi yang lebih besar dari 0,05 yaitu sebesar 0,995. Sehingga dapat disimpulkan distribusi populasi pada penelitian ini normal.

\section{Pengujian Hipotesis}

\section{Uji t}

Berdasarkan tabel 8 (Terlampir), hasil uji $\mathrm{t}$, dapat dijelaskan bahwa nilai $\mathrm{t}$ tabel sebesar 1,985. Pada variabel pemahaman perpajakan diperoleh nilai $t$ hitung 2,391, maka menunjukkan hasil bahwa $\mathrm{t}$ hitung > t tabel yaitu 2,391 > 1,985 dan nilai signifikansi $0,019<0,05$. Sehingga dapat disimpulkan, Ha diterima dan Ho ditolak yaitu bahwa variabel pemahaman perpajakan berpengaruh terhadap tindakan penggelapan pajak. Pada variabel sistem perpajakan diperoleh nilai $\mathrm{t}$ hitung 5,610, maka menunjukkan hasil bahwa $\mathrm{t}$ hitung $>\mathrm{t}$ tabel yaitu 5,610> 1,985 dan nilai signifikansi $0,000<0,05$. Sehingga dapat disimpulkan, Ha diterima dan Ho ditolak yaitu bahwa variabel sistem perpajakan berpengaruh terhadap tindakan penggelapan pajak. Pada variabel keadilan diperoleh nilai $t$ hitung 1,797, maka menunjukkan hasil bahwa t hitung < t tabel yaitu $1,797<1,985$ dan nilai signifikansi $0,076>0,05$. Sehingga dapat disimpulkan, Ho diterima dan Ha ditolak yaitu bahwa variabel keadilan tidak berpengaruh 
terhadap tindakan penggelapan pajak. Pada variabel diskriminasi diperoleh nilai $t$ hitung 2,668, maka menunjukkan hasil bahwa $\mathrm{t}$ hitung > t tabel yaitu 2,668 > 1,985 dan nilai signifikansi $0,009<0,05$. Sehingga dapat disimpulkan, Ha diterima dan Ho ditolak yaitu bahwa variabel diskriminasi berpengaruh terhadap tindakan penggelapan pajak.

\section{Uji F}

Berdasarkan hasil uji $F$ pada tabel 9 (Terlampir), diketahui bahwa nilai $\mathrm{F}$ hitung sebesar 17,736 dengan signifikansi sebesar 0,000 . Sedangkan, untuk nilai $F$ tabel 2,467. Hal ini menunjukkan pada uji $F$ bahwa $\mathrm{F}$ hitung > F tabel yaitu 17,736 > 2,467 dengan nilai signifikansi $0,000<$ 0,05 . Sehingga dapat disimpulkan bahwa Ha diterima dan Ho ditolak, yaitu variabel pemahaman perpajakan, sistem perpajakan, keadilan, diskriminasi secara bersama-sama atau simultan berpengaruh terhadap tindakan penggelapan pajak.

\section{Uji Koefisien Determinasi $\left(\mathbf{R}^{2}\right)$}

Berdasarkan tabel 10 (Terlampir) hasil uji koefisien determinasi diatas, diperoleh nilai $\mathrm{R}$ sebesar 0,654 . Hal ini berarti korelasi antara variabel independen yaitu pemahaman perpajakan, sistem perpajakan, keadilan, diskriminasi terhadap variabel dependen tindakan penggelapan pajak terjadi hubungan yang semakin erat, karena nilai $\mathrm{R}$ sebesar 0,654 mendekati 1. Sedangkan untuk nilai Adjusted R Square sebesar 0,403 atau $40,3 \%$ dan sisanya $59,7 \%$. Hal ini berarti, sumbangan pengaruh variabel independen pemahaman perpajakan, sistem perpajakan, keadilan, diskriminasi terhadap variabel dependen tindakan penggelapan pajak sebesar 40,3\%. Dan sisanya sebesar $59,7 \%$ dipengaruhi oleh variabel lain yang tidak dimasukkan dalam model ini.

\section{Pembahasan}

Hasil penelitian menunjukkan bahwa, variabel pemahaman perpajakan berpengaruh terhadap tindakan penggelapan pajak. Hasil ini sejalan dengan penelitian yang dilakukan oleh Rachmadi (2014) yang menyatakan bahwa pemahaman perpajakan berpengaruh signifikan terhadap persepsi wajib pajak atas perilaku penggelapan pajak. Hal ini berarti, apabila pengetahuan dan pemahaman wajib pajak dalam hal perpajakan mengenai aturan, tata cara, tentang ketentuan perpajakan ketika melakukan kewajiban perpajakan semakin baik, maka tidak akan menganggap tindakan penggelapan pajak sebagai perilaku pantas bahkan menghindari perilaku tersebut.

Selain itu, dalam penelitian ini juga menunjukkan bahwa variabel sistem perpajakan berpengaruh terhadap tindakan penggelapan pajak. Hasil ini mendukung penelitian yang dilakukan oleh Nickerson, et al (2009) dan Rahman (2013) yang menunjukkan bahwa sistem perpajakan berpengaruh secara positif terhadap persepsi wajib pajak mengenai etika penggelapan pajak. Artinya, jika dana pajak dapat dikelola dengan semestinya, mekanisme dalam sistem perpajakan yang tidak rumit dan mudah dipahami serta pihak fiskus yang profesional maka wajib pajak akan melaporkan kewajiban pajaknya dengan jujur.

Kemudian pada penelitian ini juga menyatakan variabel keadilan tidak berpengaruh terhadap tindakan penggelapan pajak. Hasil ini sesuai dengan penelitian yang dilakukan oleh Ayu \& Hastuti (2009) dan Suminarsasi \& Supriyadi (2012) yang menyatakan bahwa persepsi terhadap keadilan sistem perpajakan berpengaruh negatif terhadap tax evasion. Hasil ini membuktikan bahwa jika tingkat keadilan rendah, maka ketaatan wajib pajak untuk membayar pajak juga rendah, sehingga akan lebih condong untuk melakukan tindakan pajak. Hal ini dikarenakan pengelolaan dana pajak oleh pemerintah, belum dirasakan maksimal oleh masyarakat. Sehingga, pemerintah harus meningkatkan keadilan dalam pemungutan dan pengalokasian dana pajak. 
Penelitian ini menyatakan bahwa variabel diskriminasi berpengaruh terhadap tindakan penggelapan pajak. Hasil ini sejalan dengan penelitian yang dilakukan oleh Suminarsasi \& Supriyadi (2012) dan Rahman (2013) yang menyatakan bahwa terdapat pengaruh positif secara parsial antara diskrimanasi terhadap penggelapan pajak. Hal ini menjelaskan bahwa, adanya ketentuan mengenai zona bebas pajak dan salah satu kebijakan diperbolehkannya zakat sebagai elemen pengurang kewajiban perpajakan yang hanya menguntungkan sebagian kelompok masyarakat saja, sementara sebagian kelompok lain merasa dirugikan.

\section{PENUTUP}

\section{Kesimpulan}

Berdasarkan hasil analisa yang menggunakan analisis regresi berganda, dan pembahasan dari data yang yang telah dikumpulkan serta pengujian yang dilakukan, maka dapat diambil kesimpulan bahwa pada uji parsial, variabel pemahaman perpajakan berpengaruh terhadap tindakan penggelapan pajak, hasil ini sejalan dengan penelitian yang dilakukan oleh Rachmadi (2014). Hal ini berarti, bahwa jika masyarakat paham mengenai fungsi dan peraturan perpajakan, maka kemungkinan terjadinya penggelapan pajak akan semakin rendah. Variabel sistem perpajakan berpengaruh terhadap tindakan penggelapan pajak, hasil ini mendukung penelitian yang dilakukan oleh Rahman (2013). Hal ini menunjukkan, bahwa apabila sistem perpajakan berjalan dengan baik dan memberikan kemudahan wajib pajak dalam melaporkan kewajiban pajaknya serta kinerja dari petugas pajak yang professional, maka akan meminimalkan adanya penggelapan pajak. Variabel keadilan tidak berpengaruh terhadap tindakan penggelapan pajak, hasil ini sesuai dengan penelitian yang dilakukan oleh Suminarsasi \& Supriyadi (2012). Hal ini membuktikan bahwa, tingkat keadilan

\section{DAFTAR PUSTAKA}

dalam pemerataan output dari perpajakan masih rendah sehingga masih perlu ditingkatkan. Variabel diskriminasi berpengaruh terhadap tindakan penggelapan pajak, hasil ini sejalan dengan penelitian yang dilakukan oleh Suminarsasi \& Supriyadi (2012). Hal ini berarti, jika kebijakan yang ditentukan hanya menguntungkan sebagian pihak saja, maka akan timbul penentangan dari masyarakat yang mengakibatkan tindakan penggelapan pajak. Pada uji simultan, variabel pemahaman perpajakan, sistem perpajakan, keadilan dan diskriminasi berpengaruh secara bersama-sama terhadap tindakan penggelapan pajak.

\section{Keterbatasan Penelitian}

Keterbatasan dalam penelitian ini hanya menggunakan empat variabel mempengaruhi tindakan penggelapan pajak. Sampel pada penelitian ini hanya pada wajib pajak orang pribadi pengusaha, dengan teknik pengambilan data menggunakan convenience sampling sehingga jumlah sampel yang didapat hanya terbatas. Selain itu, data penelitian didapat melalui kuesioner yang dibagikan langsung kepada responden, dan memungkinkan terjadinya perbedaan penafsiran saat mengisi kuesioner.

\section{Saran}

Untuk penelitian selanjutnya diharapkan dapat menambah variabel penelitian yang dapat mempengaruhi penggelapan pajak dan sampel penelitian bisa memakai wajib pajak badan, sehingga tidak hanya pada wajib pajak orang pribadi pengusaha. Selain itu, pemerintah diharapkan lebih meningkatkan sosialisasi mengenai pentingnya pajak dan fungsinya sehingga masyarakat akan lebih paham mengenai pajak. Serta, dalam pembuatan kebijakan peerlunya pertimbangan yang berkaitan dengan diskriminasi, agar tidak terjadi kecemburuan antar wajib pajak. 
Ayu, S. D., \& Hastuti, R. (2009). Persepsi Wajib Pajak : Dampak Pertentangan Diametral Pada Tax Evasion Wajib Pajak Dalam Aspek Kemungkinan Terdeteksinya Kecurangan, Keadilan, Ketepatan Pengalokasian, Teknologi Sistem Perpajakan, Dan Kecenderungan Personal. (Studi Wajib Pajak Orang Priba. Jurnal Kajian Akuntansi UNIKA Soegijapranata Vol. 1 No. 1 ISSN 1979-4886, 1-12.

Danandjaja, J. (2003). Diskriminasi Terhadap Minoritas Masih Merupakan Masalah Aktual di Indonesia Sehingga Perlu Ditanggulangi Segera.

Ghozali, I. (2011). Aplikasi Analisis Multivariate Dengan Program IBM SPSS 19, Edisi 5. Semarang: Badan Penerbit Universitas Diponegoro.

Ghozali, I. (2006). Aplikasi Analisis Multivariate dengan SPSS. Semarang: Badan Penerbit Universitas Diponegoro.

Gibson, J. L. (2001). Terjemahan oleh Agung Wicaksono. 1997. Organisasi dan Manajemen; Perilaku, Struktur dan Proses. Jakarta: Erlangga.

Hamid, A. (2010). Buku Panduan Penulisan Skripsi. Jakarta.

Mardiasmo. (2009). Perpajakan Edisi Revisi 2009. Yogyakarta: Andi.

Mardiasmo. (2011). Perpajakan Edisi Revisi 2011. Yogyakarta: Andi.

Mutia, S. P. (2014). Pengaruh Sanksi Perpajakan, Kesadaran Perpajakan, Pelayanan Fiskus, Dan Tingkat Pemahaman Terhadap Kepatuhan Wajib Pajak Orang Pribadi (Studi Empiris pada Wajib Pajak Orang Pribadi yang terdaftar di KPP Pratama Padang). Universitas Negeri Padang .

Nickerson, I., Pleshko, L., \& McGee, R. W. (2009). Presenting the Dimensionality of An Ethics Scale pertaining To Tax Evasion. Journal of Legal, Ethical and Regulatory Issues, Volume 12 Number 1.
Ningsih, D. N., \& Pusposary, D. (2014). Determinan Persepsi Mengenai Etika atas Penggelapan Pajak (Tax Evasion) (Studi pada Mahasiswa Jurusan Akuntansi Fakultas Ekonomi dan Bisnis Universitas Brawijaya). Universitas Brawijaya.

Nurmantu, S. (2003). Pengantar Perpajakan. Jakarta: Granit.

Prasetyo, S. (2010). Persepsi Etis Penggelapan Pajak Bagi Wajib Pajak Di Wilayah Surakarta. Dalam Skripsi. Surakarta: Universitas Sebelas Maret.

Priyatno, D. (2009). 5 Jam Belajar Olah Data dengan SPSS 17. Yogyakarta: Andi.

Rachmadi, W. (2014). Faktor-Faktor Yang Mempengaruhi Persepsi Wajib Pajak Orang Pribadi Atas Perilaku Penggelapan Pajak (Studi Empiris Pada Wajib Pajak Terdaftar di KPP Pratama Semarang Candisari). Dalam Skripsi. Semarang: Universitas Diponegoro.

Rahman, I. S. (2013). Pengaruh Keadilan, Sistem Perpajakan ,Diskriminasi dan kemungkinan terdeteksi kecurangan Terhadap Persepsi Wajib Pajak Mengenai etika Penggelapan Pajak. Dalam Skripsi. Jakarta: Universitas Islam Negeri Syarif Hidayatullah.

Republik Indonesia, Undang-undang No. 6 Tahun 1983 Tentang Ketentuan Umum dan Tata Cara Perpajakan sebagaimana telah diubah dengan Undang-undang Nomor 16 Tahun 2009.

Republik Indonesia, Undang-Undang No. 7 Tahun 1983 Tentang Pajak Penghasilan sebgaimana telah diubah dengan Undang-undang Nomor 36 Tahun 2008.

Republik Indonesia, Peraturan Pemerintah Nomor 46 Tahun 2013 tentang Pajak Penghasilan atas penghasilan dari usaha yang diterima atau diperoleh wajib pajak yang memiliki peredaran bruto tertentu. 
Sholichah, I. (2005). Perilaku Wajib Pajak Terhadap Tingkat Keberhasilan Penerimaan Pajak Bumi dan Bangunan di Kabupaten Gresik. Jurnal Logos, Vol 3 No. 1, Juli $2005,62-75$.

Siahaan, M. P. (2010). Hukum Pajak Elementer. Yogyakarta: Graha Ilmu.
Suminarsasi, W., \& Supriyadi. (2012). Pengaruh Keadilan, Sistem Perpajakan dan Diskriminasi Terhadap Persepsi Wajib Pajak Mengenai Penggelapan Pajak (Tax Evasion). Universitas Gadjah Mada . 


\section{LAMPIRAN}

Tabel 1

Kriteria Pengujian Durbin Watson

\begin{tabular}{lll}
\hline \multicolumn{1}{c}{ Jika } & \multicolumn{1}{c}{ Hipotesis nol } & \multicolumn{1}{c}{ Keputusan } \\
\hline $\mathrm{D}<\mathrm{d}<\mathrm{dl}$ & Tidak ada autokorelasi positif & Tolak \\
\hline $\mathrm{D} \mathrm{l} \leq \mathrm{d} \leq \mathrm{du}$ & Tidak ada autokorelasi positif & No decision \\
\hline $4-\mathrm{dl}<\mathrm{d}<4$ & Tidak ada autokorelasi negatif & Tolak \\
\hline $4-\mathrm{du} \leq \mathrm{d} \leq 4-\mathrm{dl}$ & Tidak ada autokorelasi negatif & No decision \\
\hline $\mathrm{Du}<\mathrm{d}<4-\mathrm{du}$ & $\begin{array}{l}\text { Tidak ada autokorelasi positif } \\
\text { negative }\end{array}$ & Tidak ditolak \\
\hline
\end{tabular}

Sumber: (Priyatno, 2009)

Tabel 2

Uji Statistik Deskriptif

Descriptive Statistics

\begin{tabular}{llrrrr}
\hline & N & Minimum & Maximum & Mean & Std. Deviation \\
\hline Pemahaman Perpajakan & 100 & 12 & 15 & 13.26 & 1.070 \\
Sistem Perpajakan & 100 & 10 & 16 & 13.45 & 1.403 \\
Keadilan & 100 & 9 & 14 & 11.73 & 1.270 \\
Diskriminasi & 100 & 8 & 14 & 11.26 & 1.447 \\
Penggelapan Pajak & 100 & 11 & 19 & 15.04 & 1.809 \\
Valid N (listwise) & 100 & & & & \\
\hline
\end{tabular}

Tabel 3

Hasil Uji Validitas

\begin{tabular}{lcccc}
\hline \multicolumn{2}{c}{ Keterangan } & Nilai $\mathbf{r}_{\text {hitung }}$ & Nilai r tabel & Kriteria \\
\hline Pemahaman Perpajakan & Pertanyaan 1 & 0,691 & 0,361 & Valid \\
& Pertanyaan 2 & 0,750 & 0,361 & Valid \\
& Pertanyaan 3 & 0,764 & 0,361 & Valid \\
& Pertanyaan 4 & 0,831 & 0,361 & Valid \\
Sistem Perpajakan & Pertanyaan 1 & 0,881 & 0,361 & Valid \\
& Pertanyaan 2 & 0,789 & 0,361 & Valid \\
& Pertanyaan 3 & 0,617 & 0,361 & Valid \\
\multirow{5}{*}{ Keadilan } & Pertanyaan 4 & 0,894 & 0,361 & Valid \\
& Pertanyaan 1 & 0,749 & 0,361 & Valid \\
& Pertanyaan 2 & 0,792 & 0,361 & Valid \\
& Pertanyaan 3 & 0,827 & 0,361 & Valid \\
Diskriminasi & Pertanyaan 4 & 0,857 & 0,361 & Valid \\
& Pertanyaan 1 & 0,705 & 0,361 & Valid \\
& Pertanyaan 2 & 0,874 & 0,361 & Valid \\
& Pertanyaan 3 & 0,901 & 0,361 & Valid \\
Penggelapan Pajak & Pertanyaan 4 & 0,659 & 0,361 & Valid \\
& Pertanyaan 1 & 0,766 & 0,361 & Valid \\
& Pertanyaan 2 & 0,734 & 0,361 & Valid \\
& Pertanyaan 3 & 0,704 & 0,361 & Valid \\
& Pertanyaan 4 & 0,784 & 0,361 & Valid \\
\hline
\end{tabular}


Tabel 4

Hasil Pengujian Reliabilitas

\begin{tabular}{lccc}
\hline \multicolumn{1}{c}{ Variabel } & $\begin{array}{c}\text { Cronbach's } \\
\text { Alpha }\end{array}$ & $\begin{array}{c}\text { Jumlah } \\
\text { item }\end{array}$ & Keterangan \\
\hline Pemahaman Perpajakan & 0,747 & 4 & Reliabel \\
Sistem Perpajakan & 0,815 & 4 & Reliabel \\
Keadilan & 0,815 & 4 & Reliabel \\
Diskriminasi & 0,794 & 4 & Reliabel \\
Penggelapan Pajak & 0,729 & 4 & Reliabel \\
\hline
\end{tabular}

Tabel 5

Hasil Uji Normalitas

One-Sample Kolmogorov-Smirnov Test

\begin{tabular}{llr}
\hline & & $\begin{array}{c}\text { Unstandardisz } \\
\text { ed Residual }\end{array}$ \\
\hline $\mathrm{N}$ & Mean & 100 \\
Normal Parameter & a,b & .0000000 \\
& Std. Deviation & 1.36845542 \\
Most Extreme Difference & Absolute & .042 \\
& Positive & .042 \\
& Negative & -.038 \\
Kolmogorov-Smirnov Z & & .416 \\
Asymp. Sig. (2-tailed) & & .995 \\
\hline
\end{tabular}

Tabel 6

Hasil Uji Multikolinearitas

Coefficients $^{a}$

\begin{tabular}{|c|c|c|c|c|c|c|c|}
\hline \multirow{2}{*}{ Model } & \multicolumn{3}{|c|}{$\begin{array}{cc}\text { Unstandardized } & \text { Standardized } \\
\text { Coefficients } & \text { Coefficients }\end{array}$} & \multirow{2}{*}{$\mathrm{T}$} & \multirow{2}{*}{ Sig. } & \multicolumn{2}{|c|}{$\begin{array}{l}\text { Collinearity } \\
\text { Statistics }\end{array}$} \\
\hline & $\mathrm{B}$ & Error & Beta & & & Tolerance & VIF \\
\hline 1 (Constant) & -2.589 & 2.268 & & -1.142 & .256 & & \\
\hline Pemahaman Perpajakan & .331 & .138 & .196 & 2.391 & .019 & .900 & 1.112 \\
\hline Sistem Perpajakan & .584 & .104 & .453 & 5.610 & .000 & .925 & 1.081 \\
\hline Keadilan & .205 & .114 & .144 & 1.797 & .076 & .940 & 1.064 \\
\hline Diskriminasi & .265 & .099 & .212 & 2.668 & .009 & .955 & 1.048 \\
\hline
\end{tabular}

Tabel 7

Hasil Uji Autokorelasi

Model Summary ${ }^{\mathrm{D}}$

\begin{tabular}{crrrrr}
\hline Model & $\mathrm{R}$ & R Square & $\begin{array}{c}\text { Adjusted R } \\
\text { Square }\end{array}$ & $\begin{array}{c}\text { Std. Error of the } \\
\text { Estimate }\end{array}$ & $\begin{array}{l}\text { Durbin- } \\
\text { Watson }\end{array}$ \\
\hline 1 & $.654^{\mathrm{a}}$ & .428 & .403 & 1.397 & 1.801 \\
\hline
\end{tabular}


Gambar 1

Hasil Uji Heteroskedastisitas

Scatterplot

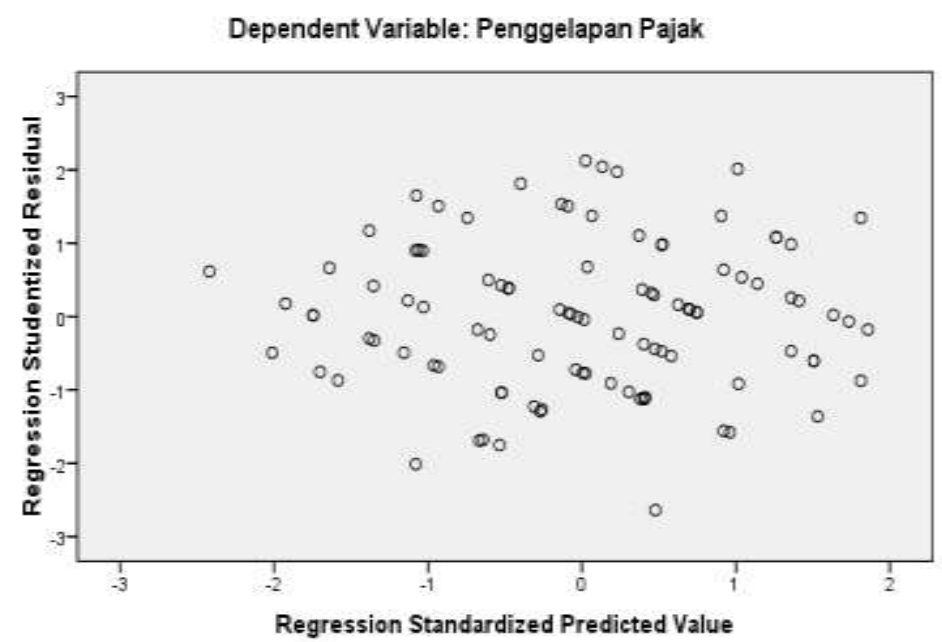

Tabel 8

Hasil Uji t

Coefficients $^{a}$

\begin{tabular}{llrrrrr}
\hline \multicolumn{1}{c}{ Model } & \multicolumn{2}{c}{$\begin{array}{c}\text { Unstandardized } \\
\text { Coefficients }\end{array}$} & $\begin{array}{c}\text { Standardized } \\
\text { Coefficients }\end{array}$ & T & Sig. \\
& B & Std. Error & Beta & & \\
\hline 1 (Constant) & -2.589 & 2.268 & & -1.142 & .256 \\
Pemahaman Perpajakan & .331 & .138 & .196 & 2.391 & .019 \\
Sistem Perpajakan & .584 & .104 & .453 & 5.610 & .000 \\
Keadilan & .205 & .114 & .144 & 1.797 & .076 \\
Diskriminasi & .265 & .099 & .212 & 2.668 & .009 \\
\hline
\end{tabular}

Tabel 9

Hasil Uji F

ANOVA $^{\circ}$

\begin{tabular}{|c|c|c|c|c|c|c|}
\hline & Model & Sum of Squares & $D f$ & Mean Square & $\mathrm{F}$ & Sig. \\
\hline \multirow[t]{3}{*}{1} & Regression & 138.446 & 4 & 34.611 & 17.736 & $.000^{\mathrm{a}}$ \\
\hline & Residual & 185.394 & 95 & 1.952 & & \\
\hline & Total & 323.840 & 99 & & & \\
\hline
\end{tabular}

Tabel 10

Hasil Uji Koefisien Determinasi $\left(\mathbf{R}^{2}\right)$ Model Summary ${ }^{\mathrm{D}}$

\begin{tabular}{crrrrr}
\multicolumn{6}{c}{ Model Summary } \\
\hline Model & $\mathrm{R}$ & R Square & $\begin{array}{c}\text { Adjusted R } \\
\text { Square }\end{array}$ & $\begin{array}{c}\text { Std. Error of the } \\
\text { Estimate }\end{array}$ & Durbin-Watson \\
\hline 1 & $.654^{\mathrm{a}}$ & .428 & .403 & 1.397 & 1.801 \\
\hline
\end{tabular}

